\title{
Cytotoxic and HIV-1 enzyme inhibitory activities of Red Sea marine organisms
}

\author{
Mona S Ellithey ${ }^{1}$, Namrita Lall ${ }^{2}$, Ahmed A Hussein ${ }^{3}$ and Debra Meyer ${ }^{1 *}$
}

\begin{abstract}
Background: Cancer and HIV/AIDS are two of the greatest public health and humanitarian challenges facing the world today. Infection with HIV not only weakens the immune system leading to AIDS and increasing the risk of opportunistic infections, but also increases the risk of several types of cancer. The enormous biodiversity of marine habitats is mirrored by the molecular diversity of secondary metabolites found in marine animals, plants and microbes which is why this work was designed to assess the anti-HIV and cytotoxic activities of some marine organisms of the Red Sea.

Methods: The lipophilic fractions of methanolic extracts of thirteen marine organisms collected from the Red Sea (Egypt) were screened for cytotoxicity against two human cancer cell lines; leukaemia (U937) and cervical cancer (HeLa) cells. African green monkey kidney cells (Vero) were used as normal non-malignant control cells. The extracts were also tested for their inhibitory activity against HIV-1 enzymes, reverse transcriptase (RT) and protease (PR).

Results: Cytotoxicity results showed strong activity of the Cnidarian Litophyton arboreum against U-937 $\left(I C_{50} ; 6.5 \mu \mathrm{g} / \mathrm{ml} \pm 2.3\right.$ ) with a selectivity index (SI) of 6.45, while the Cnidarian Sarcophyton trochliophorum showed strong activity against HeLa cells $\left(\mathrm{IC}_{50} ; 5.2 \mu \mathrm{g} / \mathrm{ml} \pm 1.2\right)$ with an $\mathrm{SI}$ of 2.09. Other species showed moderate to weak cytotoxicity against both cell lines. Two extracts showed potent inhibitory activity against HIV-1 protease; these were the Cnidarian jelly fish Cassiopia andromeda $\left({ }^{\left(C_{50}\right.} ; 0.84 \mu \mathrm{g} / \mathrm{ml} \pm 0.05\right)$ and the red algae Galaxura filamentosa $(2.6 \mu \mathrm{g} / \mathrm{ml} \pm 1.29)$. It is interesting to note that the most active extracts against HIV-1 PR, C. andromeda and G. filamentosa showed no cytotoxicity in the three cell lines at the highest concentration tested $(100 \mu \mathrm{g} / \mathrm{ml})$.
\end{abstract}

Conclusion: The strong cytotoxicity of the soft corals L. arboreum and S. trochliophorum as well as the anti-PR activity of the jelly fish C. andromeda and the red algae G. filamentosa suggests the medicinal potential of crude extracts of these marine organisms.

Keywords: Red Sea, Marine organisms, Cytotoxicity, HIV-1 protease and HIV-1 reverse transcriptase

\section{Background}

Life-threatening illnesses such as cancer and the acquired immunodeficiency syndrome (AIDS) presents patients and their families with considerable burdens. For many sufferers both cancer and AIDS have evolved from acutely terminal conditions into chronic illnesses characterized by complex psychosocial and physical issues.

The number of people living with HIV/AIDS in 2010 was estimated to be around 34 million [1]. On the other hand a total of 1,638,910 new cancer cases and 577,190 deaths from cancer were determined to have occurred in

\footnotetext{
* Correspondence: Debra.Meyer@up.ac.za

${ }^{1}$ Department of Biochemistry, University of Pretoria, 0002 Pretoria, South Africa

Full list of author information is available at the end of the article
}

the United States in 2012 [2]. Lower CD4 (white blood cell) counts and a weakened immune system are risk factors for pre-cervical and cervical cancer. Additionally, women with HIV are more likely to have a recurrence of pre-cervical cancer and antiretroviral therapy did not protect HIV-positive women from the development of pre-cervical cancer [3-5].

In order to combat both cancer and HIV/AIDS, colossal amounts of money, manpower, time and energy have been dedicated to research on novel compounds which can be developed as therapeutic agents [2]. Anti-cancer drugs and HIV treatment are related since nucleotide analogues can be used for the treatment of both diseases. Using natural products to manufacture drugs is an

\section{Biomed Central}


ancient and well established practice that has yielded familiar products such as morphine, digitalis, penicillin, and aspirin [6].

Mankind has known for thousands of years that marine organisms contain substances capable of potent biological activity which has recently also been demonstrated against different types of cancer and HIV/AIDS [7]. Natural product screening has been a component of drug-lead development for the better part of 20 years. Novel pharmaceuticals, such as taxol, have been discovered through the screening of extracts from plants, microorganisms and marine organisms [8], while in vitro inhibition of key enzymes of the viral life cycle serves as a first step in HIV/AIDS drug development.

The studies on the antiviral activities of marine natural products are presently attracting more and more attention worldwide. Marine derived compounds have been shown to have a variety of bioactivities such as antiviral, anticoagulant, antioxidant and other medicinal properties [9]. HIV-1 enzymes RT and PR were identified early on as potential drug targets. The discovery and development of inhibitors of these enzymes are an unqualified success of modern pharmacology and structural biology [10]. The emergence of drug-induced mutations of HIV1 enzymes leads to rapid loss of the potency of existing drugs and the need to develop new candidates [11].

The Red sea represents one of the most promising areas as a source of medicinal natural products. Most of the investigations into the biological activities of organisms from the Red Sea was conducted either in the northern part of gulf Aqaba [12,13] or the southern part of the sea and reported on the organisms' free radical scavenging and cancer growth inhibition activities [14-16]. These areas are subject to tourism and human impact, which can extensively affect the marine community. As reported by "Zalul," an Israeli environmental lobby group, 'over the past five years the most northerly part of the Red Sea coral reef is now 70\% dead' [17].

The study area investigated in the current report, Sharm El-Sheikh, is located in the connection point of the south Suez Gulf and south Aqaba Gulf. Most of this region is protected by the Egyptian Ministry of State For Environmental Affairs. Despite its high water quality, there are no published reports for the biological activities of marine organisms from Sharm El-Sheikh which prompted the present investigation.

This study was designed to investigate the potential cytotoxic and anti-HIV activities of thirteen marine organisms collected from Sharm El-Sheikh, Red Sea (Egypt).

\section{Methods}

Marine organisms

Thirteen of the most abundant marine organisms from different families were collected from Nabq and Ras
Mohammed protected areas (Sharm el-Sheikh, Red Sea, Egypt) in the period between March and April 2010. Fifty gram (50 g) of each sample was collected according to the sampling and preservation protocol of Kathrina Fabricius [18]. The material was collected and identified by Mona Ellithey, co-author of this article, using Red sea invertebrates' reference guide [19] which also provided detailed information specimen classification as indicated per organism below. A voucher specimen has been deposited in the Marine Natural products laboratory, NRC (Egypt) with deposition number 10/1:13. Samples were collected from different marine environments. Two sponges; Spongia officinalis (Linnaeus, 1759), Haliclona rubens (sensu Duchassaing \& Michelotti, 1864) and the jelly fish Cassiopea andromeda (Forskål, 1775) were collected from 0.6-1 m depth of mangrove swamps. The sandy bottom was used for collection of the algae Cymodocea rotundata (Ehrenberg \& Hemprich ex Ascherson 1870), Caulerpa prolifera (Forsskål J.V. Lamouroux 1809) and the gastropod Bulla ampulla (Linnaeus, 1758), from depths of 30-60 cm. From the stony bottom of the coral reef the algae Galaxaura filamentosa (W.R. Taylor 1945), the soft corals Litophyton arboreum (Forskål, 1775), Sarcophyton trochliophorum (Von Marenzeller, 1886), Sinularia heterospiculata, Sinularia maxima, Sinularia polydactyla (Verseveldt, J. 1976) and Turbinaria turbinatea (Linnaeus Kuntze 1898) were collected at depths of 1-3 m.

\section{Extract preparation}

Fresh marine organisms (50 g each) were homogenized directly after collection with $150 \mathrm{ml}$ of $90 \%$ methanol (Merck, Germany). After filtration the solvent was evaporated under reduced pressure using a rotary evaporator (Buchi, Switzerland) and the residues re-suspended in water and partitioned with ethyl acetate in order to get rid of the salts and the high molecular weight hydrophilic compounds. The lipophilic fractions obtained by ethyl acetate were dried out by rotavapor and were then tested for their in vitro cytotoxicity against two human cancer cell lines (U937) and (HeLa), and the African green monkey kidney cell line (Vero) as representative of a normal, non-cancerous cell line. The extracts were also tested for inhibitory activity in direct enzyme assays against HIV-1 reverse transcriptase and HIV-1 protease.

\section{Cell culture and cytotoxicity of extracts}

Chemicals and reagents; all cell lines, media, trypsinEDTA, fetal bovine serum (FBS) and antibiotics (penicillin, streptomycin and fungizone) were purchased from Highveld Biological (Pty) Ltd. (Modderfontein, Johannesburg, RSA).

The ethyl acetate extracts were each dissolved in DMSO to a stock solution of $20 \mathrm{mg} / \mathrm{mL}$ and added to the microtitre plate. Serial dilutions were made to range 
from a concentration of $(400 \mu \mathrm{g} / \mathrm{ml}$ to $3.12 \mu \mathrm{g} / \mathrm{ml})$ for each extract. The negative control wells included cells exposed to $2 \%$ DMSO. And the positive control Actinomycin $\mathrm{D}$ with concentrations ranging between $0.5 \mu \mathrm{g} / \mathrm{mL}$ and $0.002 \mu \mathrm{g} / \mathrm{mL}$. The microtitre plate was incubated for a further $72 \mathrm{~h}$. and were tested for their cytotoxic activity using the 2,3-bis-(2-methoxy-4-nitro- 5-sulfophenyl)-2H-tetrazolium-5-carboxanilide, Na2) (XTT) colorimetric assay. The assay is based on the ability of live cells to reduce the yellow water soluble XTT into an insoluble formazan product [20]. The marine extracts were first screened for their in vitro cytotoxicity at a concentration of $100 \mu \mathrm{g} / \mathrm{ml}$ against HeLa and U937 cells. Extracts which reduced > $50 \%$ of the cell proliferation of both cell lines were further tested at concentrations that ranged from $(400 \mu \mathrm{g} / \mathrm{ml}$ to $3.12 \mu \mathrm{g} / \mathrm{ml}$ ). A third non-cancerous cell line (Vero) was also included for the most active extracts in order to determine selectivity indices which represent the overall activity of the extract. Selectivity Indexes (SI) values were calculated as follows; the $50 \%$ inhibitory concentration $\left(\mathrm{IC}_{50}\right)$ of the extract tested in Vero cell line was divided by the $\mathrm{IC}_{50}$ of the extract tested in a cancer cell. Higher SI values indicate the more selective extracts.

Cells were maintained in culture flasks in complete medium supplemented with 10\% heat-inactivated FBS and antibiotic cocktail $(100 \mathrm{U} / \mathrm{mL}$ penicillin, $100 \mathrm{~g} / \mathrm{L}$ streptomycin and $250 \mathrm{~g} / \mathrm{L}$ fungizone). Cells were cultured and maintained in a humidified atmosphere at $37^{\circ} \mathrm{C}$ and $5 \%$ $\mathrm{CO}_{2}$. Cytotoxicity was measured by the XTT method using the Cell Proliferation Kit II (F. Hoffmann-La Roche Ltd.). Cells $(100 \mu \mathrm{l})$ were seeded (concentration $1 \times 10^{5}$ cells $/ \mathrm{mL}$ ) into a microtitre plate and incubated for $24 \mathrm{~h}$ to allow the cells to adhere. Following the evaporation of ethyl acetate, the extract powder residue was dissolved in DMSO and then serially diluted $(400 \mu \mathrm{g} / \mathrm{ml}$ to 3.12$)$, added to the plates and incubated for $72 \mathrm{~h}$. A positive control for cytotoxicity, actinomycin D and a negative control of cells with $2 \%$ DMSO were also included. After a $72 \mathrm{~h}$ incubation, XTT was added to a final concentration of $0.3 \mathrm{mg} / \mathrm{mL}$ and the cells incubated for $2-3 \mathrm{~h}$. Absorbance of the developed colour was spectrophotometrically determined using a multi-well plate reader which measured the optical density at $450 \mathrm{~nm}$ with a reference wavelength of $690 \mathrm{~nm}$. Mean $\mathrm{IC}_{50}$ is the concentration of extracts which reduces cell growth by $50 \%$ under the experimental conditions and is the average of at least three independent reproducible measurements. The $\mathrm{IC}_{50}$ values were performed using GraphPad Prism (San Diego, USA).

\section{HIV-1 direct enzyme assays}

Reverse transcriptase (RT) inhibitory activity of the crude extracts against a purified recombinant HIV1-RT (Merck, Darmstadt, Germany) was determined by using the Roche
Diagnostics (Mannheim, Germany) colorimtric kit. The assay was performed as previously described [21].

HIV-1 protease enzyme (Bachem Bioscience Inc. King of Prussia, PA, UK) and the substrate (a synthetic peptide that contains a cleavage site Tyr-Pro for HIV protease as well as two covalently modified amino acids for the detection of cleavage). The assay was performed according to procedures by Lam et al. [22] in black 96 well assay plates obtained from Corning Incorporated, (Corning, New York, USA). The fluorescence intensity was measured at an excitation wavelength of $355 \mathrm{~nm}$ and an emission wavelength of $460 \mathrm{~nm}$ using a synergy microplate spectrofluorometer (BioTek, Analytical \& Diagnostic products, South Africa). Acetyl pepstatin (AP) was used as a positive control for HIV-1 PR inhibition. The blank treatment consisted of assay buffer with only the substrate and an untreated control of enzyme and substrate was also included. The percentage inhibition was calculated based on the formula:

\section{0-[(Test reagent RFU-background RFU)/ (untreated control RFU-blank) × 100]}

where RFU = relative fluorescence units.

All the marine organism materials were screened at $100 \mu \mathrm{g} / \mathrm{ml}$ for inhibition of HIV-1 enzymes. $\mathrm{IC}_{50}$ values of the most active extracts were calculated and compared to known HIV-1 PR and HIV-1 RT inhibitors. All the experiments were done 3 times in order to ensure the precision and accuracy of the data.

\section{Statistical analysis}

One way ANOVA analysis was done followed by post hoc Tukey HSD tests to determine the significance of the extracts' cytotoxicity and inhibitory activities. The statistical analysis was done using IBM SPSS version 19.

\section{Results and discussion}

\section{Cytotoxicity of the extracts}

The cytotoxicity of the soft corals L. arboreum, S. polydactyla, S. maxima and S. heterospiculata were tested for the first time in U937 cells. In Figure 1 the cytotoxicity of extracts at $100 \mu \mathrm{g} / \mathrm{ml}$ is shown, indicating that these soft corals demonstrated potent cytotoxicity by killing more than $90 \%$ of the cells. Extracts of the mentioned organisms were significantly different $(\mathrm{P}<0.000)$ from the values for negative controls (see Figure 1 ).

Moderate cytotoxicity ( $<60 \%$ of cell death) was demonstrated by the soft coral $S$. trocheliophorum, the green algae $C$. prolifera, the sponges $S$. officinalis and $H$. rubens, the sea grass $C$. rondata and the brown algae T. turbinata. The lowest cytotoxicity in U937 cells was observed from the mollusc B. ampulla, the jelly fish $C$. andromeda and 


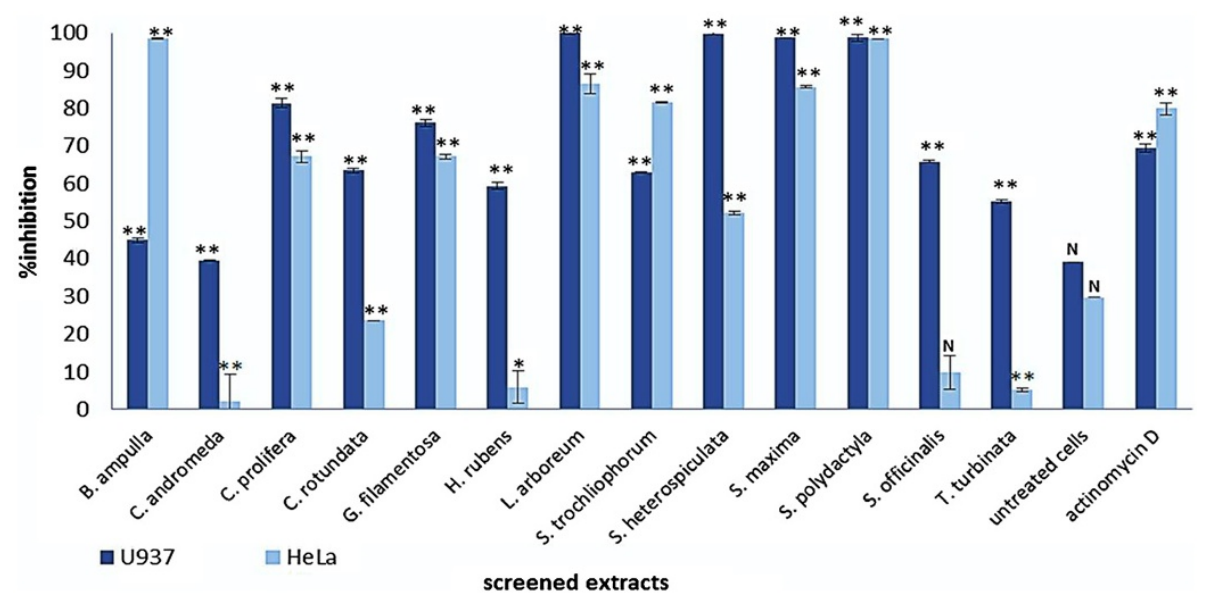

Figure 1 Cytotoxicity of different marine extracts. Samples were dissolved in DMSO and diluted with the medium to a final concentration of $100 \mathrm{\mu g} / \mathrm{ml}$. Significant differences between the extracts and the DMSO control was calculated using IBM SPPS version 19 . ${ }^{* * P}<0.00$, ${ }^{* P}<0.05$ and $\mathrm{N}$ indicates not significant.

the red algae G. filamentosa where $60 \%$ of the cells were still viable.

This is also the first report for the cytotoxicity of the mollusc B. ampulla and the soft coral S. polydactyla in HeLa cells. As shown in Figure 1, these organisms showed potent cytotoxicity by killing more than $90 \%$ of the cells when tested at $100 \mu \mathrm{g} / \mathrm{ml}$. The soft corals $L$. arboreum, S. maxima and S. trocheliophorum showed strong cytotoxicity and killed more than $80 \%$ of the cells. C. prolifera and $S$. heterospiculata showed moderate toxicity $(<60 \%)$. The lowest cytotoxicity in HeLa cells was observed for S. officinalis, T. turbinata, C. andromeda, $H$. rubens and $C$ rotundata where more than $60 \%$ of the cells were still viable.

Following these observations only potent and the strongly active extracts were subjected to detailed study to determine their half maximal inhibitory concentrations $\left(\mathrm{IC}_{50}\right)$ and selectivity indices. Once the $\mathrm{IC}_{50}$ values were determined, responses of the marine extracts were characterized according to the guidelines of the National Cancer Institute (NCI) where $\mathrm{IC}_{50}$ values of $10-20 \mu \mathrm{g} / \mathrm{ml}$ of a total/crude extract is viewed as cytotoxic, $20 \leq 50 \mu \mathrm{g} / \mathrm{ml}$ as moderately cytotoxic and $<10 \mu \mathrm{g} / \mathrm{ml}$ as strongly cytotoxic. As the selectivity index value of an extract increase the ability of the extract to target the cancer cells rather than normal body cells also increases.

As shown in Table 1, the soft coral L. arboreum presented very strong cytotoxicity and selectivity $\left(\mathrm{IC}_{50} ; 6.5 \mu \mathrm{g} /\right.$ $\mathrm{ml}, \mathrm{SI} ; 6.45)$ in U937 cells which is reported here for the first time. It also showed a moderate activity in $\mathrm{HeLa}\left(\mathrm{IC}_{50}\right.$; $28.10 \mu \mathrm{g} / \mathrm{ml}, \mathrm{SI} ; 1.46)$ as compared to the cytotoxicity positive control, Actinomycin D ( $\mathrm{IC}_{50} 7.8 \mu \mathrm{g} / \mathrm{ml}$, SI 1.5) in U937 cells and $\left(\mathrm{IC}_{50} ; 17.7 \mu \mathrm{g} / \mathrm{ml}\right.$, SI; 1.5$)$ in HeLa. The observed toxicity can be due to the terpenoids which are extensively reported in soft corals from the family Alcyoniidae [23]. Terpenoids, mainly macrocyclic cembrane-type diterpenoids and their derivatives, represent important chemical defense tools for these animals against their natural predators [24]. Results presented here are supported by current literature reporting that $L$. arboreum demonstrated moderate cytotoxicity against HUVEC, K-562 and HeLa [25], L-929 and K-562 [26] as well as strong antibacterial activity [27].

The soft coral, Sarcophyton trocheliophorum showed promising cytotoxicity with a selectivity index higher than the positive control $\left(\mathrm{IC}_{50} 5.2 \mu \mathrm{g} / \mathrm{ml}, \mathrm{SI} ; 2\right)$ in HeLa cells. In a similar study polyhydroxy sterols from $S$. trocheliophorum obtained in Singapore showed potent cell growth inhibitory activity against different human HL60 leukaemia (the present study used U937), M14 skin melanoma, and MCF7 breast carcinoma cells with $\mathrm{EC}_{50}$ values of 2.8, 4.3 , and $4.9 \mu \mathrm{g} / \mathrm{ml}$ respectively detected by the MTT assay (a related, not identical tetrazolium dye was used here), and exhibited minimal toxicity to normal human peripheral blood lymphocytes [28]. These data suggests that S. trocheliophorum from any marine environment may be producing sterols which when isolated or present in an extract retain their potency and may yet prove useful as anti-cancer drugs.

Previous studies showed that a hybridization of Sinularia polydactyla and Sinularia maxima species had strong cytotoxicity in the following cell lines; the breast cancer SK-BR3 cell line, cervical cell line, HeLa and HeLa-Apl cell lines [29]. In the current study, when the original organisms (not hybrids) were tested, S. polydactyla exhibited moderate cytotoxicity $\left(\mathrm{IC}_{50} ; 20 \mu \mathrm{g} / \mathrm{ml}\right.$, SI; $0.34)$ in HeLa cells. S. maxima had moderate toxicity $\left(\mathrm{IC}_{50} ; 24.0 \mu \mathrm{g} / \mathrm{ml}, \mathrm{SI} ; 1.8\right)$ in U937 and in HeLa cells 
Table 1 The half maximal inhibition concentration $\left(\mathrm{IC}_{50}\right)$ of the lipophilic fraction of the marine organism extracts against HIV-1 PR is presented

\begin{tabular}{|c|c|c|c|c|c|c|c|}
\hline \multirow[t]{2}{*}{ Phylum } & \multirow{2}{*}{$\begin{array}{l}\text { Marine } \\
\text { organism }\end{array}$} & \multicolumn{3}{|c|}{ Cytotoxicity $\mathrm{IC}_{50}(\mu \mathrm{g} / \mathrm{mL})$} & \multicolumn{2}{|c|}{ SI values } & \multirow{2}{*}{$\frac{\mathrm{IC}_{50}(\mu \mathrm{g} / \mathrm{mL}}{\text { HIV-1 PR }}$} \\
\hline & & U937 & HeLa & Vero & U937 & HeLa & \\
\hline Mollusca & B. ampulla & $\mathrm{N} / \mathrm{T}^{\mathrm{a}}$ & 76.53 & 110.80 & N/A & 1.4 & $\mathrm{~N} / \mathrm{T}^{\mathrm{b}}$ \\
\hline Rhodophyta & G. filamentosa & $\mathrm{N} / \mathrm{T}^{\mathrm{a}}$ & $\mathrm{N} / \mathrm{T}^{\mathrm{a}}$ & $\mathrm{N} / \mathrm{T}^{\mathrm{a}}$ & N/A & N/A & 2.6 \\
\hline Chlorophyta & C. prolifera & 52.46 & 32.32 & 143.21 & 2.73 & 4.43 & $\mathrm{~N} / \mathrm{T}^{\mathrm{b}}$ \\
\hline Phaeophyta & T. turbinatea & $N / T^{a}$ & $N / T^{a}$ & $N / T^{a}$ & N/A & N/A & $N / T^{b}$ \\
\hline Tracheophyta & C. rotundata & $N / T^{a}$ & $\mathrm{~N} / \mathrm{T}^{\mathrm{a}}$ & $\mathrm{N} / \mathrm{T}^{\mathrm{a}}$ & N/A & N/A & $\mathrm{N} / \mathrm{T}^{\mathrm{b}}$ \\
\hline Porifera & H. rubens & $N / T^{a}$ & $N / T^{a}$ & $N / T^{a}$ & N/A & N/A & $N / T^{b}$ \\
\hline Porifera & S. officinalis & $\mathrm{N} / \mathrm{T}^{\mathrm{a}}$ & $\mathrm{N} / \mathrm{T}^{\mathrm{a}}$ & $\mathrm{N} / \mathrm{T}^{\mathrm{a}}$ & N/A & $\mathrm{N} / \mathrm{A}$ & $\mathrm{N} / \mathrm{T}^{\mathrm{b}}$ \\
\hline Cnidaria & C. andromeda & $\mathrm{N} / \mathrm{T}^{\mathrm{a}}$ & $N / T^{a}$ & $N / T^{a}$ & N/A & N/A & 0.84 \\
\hline Cnidaria & S. heterospiculata & 44.54 & $\mathrm{n} / \mathrm{a}$ & 43.95 & 0.99 & $\mathrm{n} / \mathrm{a}$ & 8.6 \\
\hline Cnidaria & S. maxima & 24.00 & 30.08 & 43.95 & 1.83 & 1.46 & 13.1 \\
\hline Cnidaria & S. polydactyla & 89.05 & 20.0 & 6.80 & 0.08 & 0.34 & $\mathrm{~N} / \mathrm{T}^{\mathrm{b}}$ \\
\hline Cnidaria & L. arboreum & 6.50 & 28.10 & 41.90 & 6.45 & 1.46 & 12.0 \\
\hline Cnidaria & S. trocheliophorum & $N / T^{a}$ & 5.200 & 10.90 & N/A & 2.10 & $\mathrm{~N} / \mathrm{T}^{\mathrm{b}}$ \\
\hline Actinomycin $D^{c}$ & & 7.8 & 17.7 & 11.8 & 1.5 & 0.7 & $\mathrm{~N} / \mathrm{T}^{\mathrm{b}}$ \\
\hline Acetylpepstatin ${ }^{d}$ & & & & & & & 5.7 \\
\hline
\end{tabular}

The $\mathrm{IC}_{50}$ values were determined in different cell lines and are presented along with the associated selectivity index (SI) values which represent the relative activity towards the cancer cell lines compared to the Vero cells.

Not tested $\left(\mathrm{N} / \mathrm{T}^{\mathrm{a}}\right)$ samples with inhibitory activities less than $50 \%$ at $100 \mu \mathrm{g} / \mathrm{ml}$.

Not tested $\left(\mathrm{N} / \mathrm{T}^{\mathrm{b}}\right)$ samples with inhibitory activities less than $80 \%$ at $100 \mu \mathrm{g} / \mathrm{ml}$.

Superscript $C$ indicates the anticancer drug used as positive control for the cytotoxicity assay.

Superscript $D$ indicates the positive control used in the PR inhibition assay.

( $\left.\mathrm{IC}_{50} ; 30 \mu \mathrm{g} / \mathrm{ml}, \mathrm{SI} ; 1.46\right)$. In addition, another species that is reported here for the first time, S. heterospiculata, exhibited low cytotoxicity $\left(\mathrm{IC}_{50} ; 44.5 \mu \mathrm{g} / \mathrm{ml}\right.$, SI, 0.99$)$ in U937 and no activity in HeLa cells.

The green algae $C$. prolifera showed weak to moderate cytotoxicity in U937 and HeLa cell lines ( $\mathrm{IC}_{50} ; 52.46 \mu \mathrm{g} / \mathrm{ml}$, $32.3 \mu \mathrm{g} / \mathrm{ml}$ and SI, 2.73, 4.4) respectively. Caulerpenyne (Cau), a metabolite from Caulerpa taxifolia has previously been shown to be cytotoxic against KB cells and fibroblasts from hamsters. Cau along with 6 other drugs representative of the major classes of anticancer products were tested against 8 cancer cell lines of human origin. Cau demonstrated growth-inhibitory effects in all cases with some variability between cell lines. It was also shown to induce inhibition of SK-N-SH tumour cell proliferation with an $\mathrm{IC}_{50}$ of $10+/-2$ micro $\mathrm{M}$ [30-32]. It is there for possible that the cytoxicity demonstrated by the crude extract of C.prolifera, may increase if compounds like Cau is isolated from it. All other tested species showed moderate to weak activity against both cell lines.

The main goal of cancer chemotherapy research is to discover safe and efficient agents that target cancer cells specifically but are innocuous to normal cells. However, many anticancer drugs fail to meet this criterion being unable to discriminate between cancer and normal cells. The development of novel cancer chemotherapeutic agents with a higher potency and specificity against cancer cells is urgently needed. The selectivity index of L. arboreum in U937 and S. trocheliophorum in HeLa compares very well and even better than the positive control used in this study and is worthy of further investigation.

\section{Anti-HIV direct enzymes assays}

All the extracts were tested at $100 \mu \mathrm{g} / \mathrm{ml}$ for the inhibition of HIV-1 RT and PR enzymes. The experiment was repeated at least 3 times. Extracts with percentages of inhibition $\geq 50 \%$ were considered to be active while the extracts demonstrating $>90 \%$ inhibition were considered potent.

Unfortunately, none of the screened extracts showed any inhibitory activity of HIV-1 RT (all inhibitions were $<50 \%$ ). In cases where marine organisms were able to inhibit this enzyme, it was always pure compounds which were hydrophilic in nature, suggesting that for activity against this enzyme, more aqueous extracts should be prepared [33]. On the other hand most of the extracts inhibited HIV-1 PR enzyme in the direct assays. These data is presented in Figure 2 demonstrating that strong inhibitory activity $(>80 \%)$ were obtained by $S$. maxima, L. arboreum, B. ampulla, C. andromeda, G. filamentosa, and $S$. heterospiculata. Values of these active extracts were significantly different $(\mathrm{P}<0.00)$ from the values for negative controls (See Figure 2). S. trocheliophorum and 


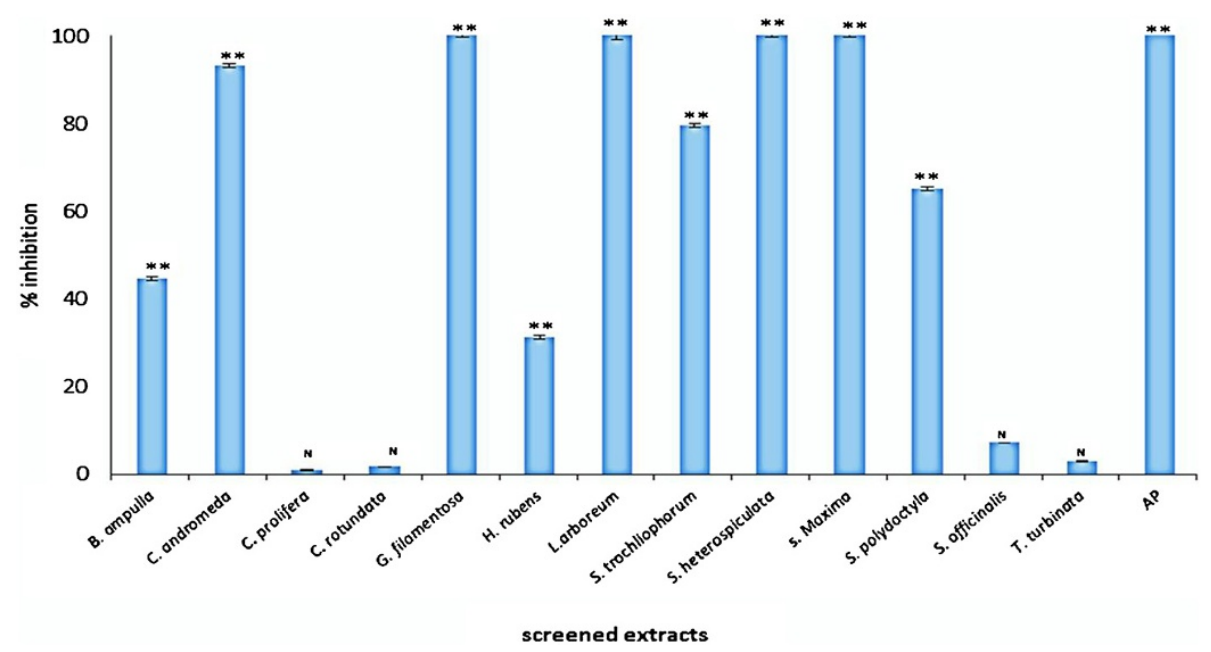

Figure 2 HIV-1 PR inhibition percentages of different marine extracts. Samples were dissolved in DMSO and diluted with the assay buffer to a final concentration of $100 \mu \mathrm{g} / \mathrm{ml}$. Significant differences between the extracts and the DMSO control was calculated using IBM SPPS version 19. ${ }^{*} \mathrm{P}<0.00,{ }^{*} \mathrm{P}<0.05$ and $\mathrm{N}$ indicates not significant. AP indicates the experimental positive control acetyl pepstatin.

S. polydactyla was active but to a lesser extent demonstrating inhibitory activities of $65-80 \%$. C rotundata and C. prolifera exhibited very weak inhibitory activity $(<50 \%)$.

Only the extracts with strong inhibitory activity were subjected to detailed study using serial dilutions of each extract in order to determine their $\mathrm{IC}_{50}$ values. Following IC50 assessments, the extract activities were classified as follows; potent activities were assigned to $\mathrm{IC}_{50}<10 \mu \mathrm{g} / \mathrm{ml}$, while $\mathrm{IC}_{50} 10<20 \mu \mathrm{g} / \mathrm{ml}$ was considered strong, and $\mathrm{IC}_{50}$ $20<50 \mu \mathrm{g} / \mathrm{ml}$ as moderate. Extracts demonstrating $\mathrm{IC}_{50}$ values of $>50 \mu \mathrm{g} / \mathrm{ml}$ were considered weak.

The detailed $\mathrm{IC}_{50}$ study showed potent inhibitory activity of HIV-1 PR by the Cnidarian jelly fish C. andromeda $\left(\mathrm{IC}_{50} 0.84 \mu \mathrm{g} / \mathrm{ml}\right)$. Phylum Cnidaria was reported to have antimicrobial [34], antioxidant [35] and anti-inflammatory [36] activities. Nothing has been reported on the anti HIV-1 or the cytotoxicity of C. andromeda until now.

In this study, the red algae G. filamentosa showed potent HIV-1 PR inhibitory activity $\left(\mathrm{IC}_{50} 2.6 \mu \mathrm{g} / \mathrm{ml}\right)$. Many studies have discussed the biological importance of marine algae. Some of the studies in search of anti-herpetic substances have been particularly interesting. The use of these organisms as botanical agents to treat viral infection resulted in four patents [37-39]. The first two patents used aqueous extracts of Neodilsea americana and $N$. integra [40] while the third patent is particularly well documented and involves the use of Cryptosiphonia woodii [41]. For the latter, clinical efficacy was clearly demonstrated. The fourth patent is for the use of carrageenan and other sulfated polysaccharides for the treatment of diseases (including AIDS) caused by retroviral infection [42]. In another study on the hydrophilic metabolites (sulfated oligo- or poly-saccharide compounds) from red algae, retroviral replication was suppressed and viral reverse transcriptase inhibited [33].

It is important to mention that our study is the first report of the promising HIV-1 protease inhibitory activity of C. andromeda $\left(\mathrm{IC}_{50} ; 0.84\right) \mu \mathrm{g} / \mathrm{ml}$ and G. filamentosa $\left(\mathrm{IC}_{50} ; 2.6 \mu \mathrm{g} / \mathrm{ml}\right)$ while the $\mathrm{IC}_{50}$ of the positive control (acetyl pepstatin) for enzyme inhibition in the assay was $5.7 \mu \mathrm{g} / \mathrm{ml}$. These extracts showed no cytotoxicity against the three cell lines at the highest concentration $(100 \mu \mathrm{g} / \mathrm{ml})$ tested.

Moderate HIV-1 PR inhibitory activities were shown by the soft corals $S$. heterospiculata $(8.6 \mu \mathrm{g} / \mathrm{ml} \pm 3.4), L$. arboreum $(12.007 \mu \mathrm{g} / \mathrm{ml} \pm 2.4)$ and $S$. maxima $(13.1 \mu \mathrm{g} / \mathrm{ml} \pm$ 2.3). Metabolites from soft corals found to have cytotoxicity against selected cancer cell lines, antiviral activity against human cytomegalo virus (HCMV), antiinflammatory activity and antibacterial activity against five selected bacterial strains, have been reported [43]. To date, no anti-HIV activity have been reported in literature for the three soft corals tested here. Enzymatic assays are an important first step when identifying potential antiHIV leads, however screening extracts and especially pure compounds in virus infected cell cultures are essential next steps to ensure that only the most promising of compounds able to inhibit whole virus replication progresses in the drug development pipe line.

\section{Conclusion}

The present study demonstrated that marine organisms remain one of the most interesting sources for the discovery of bioactive leads that can help in the treatment of cancer and HIV. This study is the first to report the anticancer and anti HIV activities of B. ampulla, C. rotundata, 
G. filamentosa, H. rubens, S. trochliophorum, S. heterospiculata, S. officinalis and T. turbinata. This is also the first report on the HIV-1 PR inhibitory activities of extracts of $C$. andromeda, C. prolifera and $L$. arboreum, S. maxima, S. polydactyla.

Although the cytotoxicity of some of the extracts reported on here, have previously been tested in the HeLa cell line (for C. prolifera, L. arboreum, S. maxima and S. polydactyla), this study is the first to report cytotoxicity of these extracts in a leukaemia cancer cell line (U937).

The bio-activity evaluation of the extracts resulted in two marine extracts demonstrating strong anticancer activity; L. arboreum in U937 cells and S. trochliophorum in HeLa with high safety margins compared to Actinomycin D. C. andromeda showed potent anti-PR activity with an $\mathrm{IC}_{50} 6$ times lower than the positive control with no cytotoxicity in the different cell lines while G. filamentosa extract showed double the activity of the positive control with higher safety margins. These findings suggest that these species could be an interesting source of bioactive compounds and deserve further bioassayguided isolation procedures to determine the identity and structure of the active compounds.

\section{Abbreviations}

HIV: Human Immunodeficiency Virus; PR: Protease; RT: Reverse transcriptase; FBS: Fetal bovine serum; $I C_{50}$ : The half maximal inhibitory concentration; SI: selectivity index; XTT: 2,3-bis-(2-methoxy-4-nitro- 5-sulfophenyl)-2H-tetrazolium-5-carboxanilide, Na2).

\section{Competing interests}

The authors declare that they have no competing interests.

\section{Authors' contributions}

$\mathrm{AH}, \mathrm{DM}$ and NL designed the study. AH and MSE was responsible for collection, identification and extraction of the samples; DM, NL and MSE performed the viability and the HIV enzymatic assays. MS wrote the first draft of the article, DM, AH; NL and MSE provided editorial and data interpretation information, all authors approved the final manuscript.

\section{Acknowledgements}

We are grateful to the Medical Research Council, the Technology Innovation Agency and the University of Pretoria, South Africa for the financial support as well as the crew of Ras Mohammed national park, Egypt for their support during sample collection.

Special thanks to Prof. Francois Steffens from the Statistics Department of the University of Pretoria, for his help with statistical analyses of the data.

\section{Author details}

${ }^{1}$ Department of Biochemistry, University of Pretoria, 0002 Pretoria, South Africa. ${ }^{2}$ Department of Plant Science, University of Pretoria, 0002 Pretoria, South Africa. ${ }^{3}$ Department of Chemistry, University of the Western Cape, Private Bag X17, Belleville 7535, South Africa.

Received: 5 June 2013 Accepted: 17 February 2014

Published: 25 February 2014

\section{References}

1. World health Organization: Global Health Sector Strategy on HIV/AIDS 2011-2015.

2. American Cancer Society: Cancer Facts \& Figures 2012. Atlanta: American Cancer Society; 2012

3. Zaporozhan V, Posokhova S, Popova T: The factors associated with cervical intraepithelial neoplasia in HIV-infected women. In Presentation at XVIII
International AIDS Conference, July 18-23 2010. www.AIDS2010.org/abstract. aspx?AIDS=2896url active 24 February 2014

4. Lodi C, Michelin M, Lima MI, Teixeira N, Adad S, Murta ED, Lucena A, Guimarães M, Murta E, Melo V: Cervical intraepithelial neoplasia recurrence after conization in HIV infected and no infected women. Arch Gynecol Obstet 2011, 284:191-197.

5. Abraham AG, D'Souza G, Jing Y, Gange SJ, Sterling TR, Silverberg MJ, Saag MS, Rourke SB, Rachlis A, Napravnik S, Moore RD, Klein MB, Kitahata MM, Kirk GD, Hogg RS, Hessol NA, Goedert JJ, Gill MJ, Gebo KA, Eron JJ, Engels EA, Dubrow R, Crane HM, Brooks JT, Bosch RJ, Strickler HD, North American AIDS Cohort Colloboration on Research and Design of leDEA: Invasive cervical cancer risk among HIV-infected women: a North American Multicohort collaboration prospective study. J. Acquir Immune Defic Syndr, 62(4):405-413. doi:10.1079/ QAl.0b013e31828177d7.

6. Newman DJ, Cragg GM: Natural products as sources of new drugs over the 30 years from 1981 to 2010. J Nat Prod 2012, 75(3):311-335.

7. Simmons TL, Andrianasolo E, McPhail K, Flatt P, Gerwick WH: Marine natural products as anticancer drugs. Molec Cancer Therapeutics 2005, 4:333-342.

8. John M: Natural products in cancer chemotherapy: past, present and future. Nat Rev Cancer 2002, 2:143-148.

9. Wei W, Shi-Xin W, Hua-Shi G: The antiviral activities and mechanisms of marine polysaccharides: an overview. Mar Drugs 2012, 10:2795-2816.

10. Francesca E, Angela C, Enzo T: HIV-1 reverse transcriptase still remains a new drug target: structure, function, classical inhibitors, and new inhibitors with innovative mechanisms of actions. Mol Biol Int 2012, 12:1-23.

11. Mark AW: The need for development of new HIV-1 reverse transcriptase and integrase inhibitors in the aftermath of antiviral drug resistance. Scientifica 2012:1-28. article id 238278. (http://dx.doi.org/10.6064/2012/ 238278).

12. Bergman $\mathrm{O}$, Mayzel B, Anderson MA, Shpigel M, Hill RT, llan M: Examination of marine-based cultivation of three demosponges for acquiring bioactive marine natural products. Mar Drugs 2011, 9:2201-2219.

13. Kelman D, Kashman Y, Rosenberg E, llan M, Yifrach I, Loya Y: Antimicrobial activity of the reef sponge Amphimedon viridis from the Red Sea: evidence for selective toxicity. Aquat Microb Ecol 2001, 24:9-16.

14. Diaa TA, Lamiaa A, Hani Z: Bioactive compounds from the red sea marine sponge Hyrtios Species. Mar Drugs 2013, 11:1061-1070.

15. Alarif WM, Abdel-lateff A, AL-lihaibi SS, Ayyad S-EN, Badria FA, Alsofyani AA, Abou-Elnaga ZS: Marine bioactive steryl esters from the red sea black coral antipathes dichotoma. Clean Soil Air Water 2013: doi:10.1002/ clen.201200409.

16. Mohamed-Elamir F, Amira M, Abdelaaty A, Fathy F, Tarik A, Bruce R, Paré W: Bioactive hydroperoxyl cembranoids from the red sea soft coral sarcophyton glaucum. Mar Drugs 2012, 10:209-222.

17. Red Sea pollution hurts Coral Reef. Copyright Associated Press 2004 found at http://www.nbcnews.com/id/5981370/ns/technology_and_sciencemsnbc_wire_services/t/group-red-sea-pollution-hurts-coral-reef/\#. Uwq8NfRg7uc.

18. Fabricius KE: Flow-dependent herbivory and growth in zooxanthellae-free soft corals. Limnol Oceanogr 1995, 40(7):290-13010.

19. Lieske E, Myers RF: Coral Reef Guide Red Sea: Red Sea to Gulf of Aden, South Oman. London GB: Harper Collins; 2004:1-384.

20. Zheng YT, Chan WL, Chan P, Huang H, Tam SC: Enhancement of the antiherpetic effect of trichosanthin by acyclovir and interferon. FEBS Lett 2001, 496:139-142

21. Fonteh PN, Keter FK, Meyer D: New bis(thiosemicarbazonate) gold(III) complexes inhibit HIV replication at cytostatic concentrations: potential for incorporation into virostatic cocktails. J Inorg Biochem 2011, 105:1173-1180.

22. Lam TL, Lam ML, Au TK, Ip DTM, Ng TB, Fong WP, Wan DCC: A comparison of human immunodeficiency virus type- 1 protease inhibition activities by the aqueous and methanol extracts of Chinese medicinal herbs. Life Sci 2000, 69:2889-2896.

23. Cheng SY, Wang SK, Chiou SF, Hsu CH, Dai CF, Chiang MY, And Duh CY: Cembranoids from the Octocoral Sarcophyton ehrenbergi. J Nat Prod 2010, 73:197-203.

24. Li Y, Gao AH, Huang H, Li J, Mollo E, Gavagnin M, Cimino G, Gu YC, Guo YW: Diterpenoids from the Hainan soft coral Sinularia parva. Helv Chim Acta 2009, 92:1341-1348. 
25. Shaker KH, Mueller M, Ghani M, Dahse H-M, Seifert K: Terpenes from the Soft Corals Litophyton arboreum and Sarcophyton ehrenbergi. Chem \& Biodiv 2010, 7(8):2007-2015.

26. Grote D, Dahse H-M, Seifert K: Furanocembranoids from the soft corals Sinularia asterolobata and Litophyton arboretum. Chem \& Biodiv 2008, B(11):2449-2456.

27. Kelman D, Kashman Y, Rosenberg E, Kushmaro A, Loya Y: Antimicrobial activity of Red Sea corals. Mar Biol 2006, 149(2):357-363.

28. Dong H, Gou YL, Kini RM, Xu HX, Chen SX, Teo SL, But PP: A new cytotoxic polyhydroxysterol from soft coral Sarcophyton trocheliophorum. Chem Pharm Bull 2000, 48(7):1087-1089.

29. Kamel HN, Ferreira D, Garcia-Fernandez LF, Slattery M: Cytotoxic diterpenoids from the hybrid soft coral sinularia maxima _ sinularia polydactyla. J Nat Prod 2007, 70(8):1223-1227.

30. Fischel JL, Lemée R, Formento P, Caldani C, Moll JL, et al: Cell growth inhibitory effects of Caulerpenyne, a sesquiterpenoid from the marine algae Caulerpa taxifolia. Anticancer Res 1995, 15:2155-2160.

31. Barbier $P$, Guise $S$, Huitorel $P$, Amade $P$, Pesando D: Caulerpenyne from Caulerpa taxifolia has an antiproliferative activeity on tumor cell line SK-N-SH and modifies the microtubulenetwork. Life Sci 2001, 70:415-429.

32. Cavas $L$, Baskin Y, Yurdakoc $K$, Olgun N: Antiproliferative and newly attributed apoptotic activities from an invasive marine alga: caulerpa racemosa var. cylindracea. J Exp Mar Biol Ecol 2006, 339:111-119.

33. Schaffrath D, Stuhslatz HW, Greiling H: Interactions of glycosaminoglycans with DNA and RNA synthesizing enzymes in vitro. Z Physiol Chem 1976, 357:499-508.

34. Radwan FF, Burnett JW, Bloom DA, Coliano T, Eldefrawi ME, Erderly H, Aurelian L, Torres M, Heimer-de la Cotera EP: A comparison of the toxinological characteristics of two Cassiopea and Aurelia species. Toxicon 2001, 39(2-3):245-257.

35. Ovchinnikova TV, Balandin SV, Aleshina GM, Tagaev AA, Leonova YF, Krasnodembsky ED, Men'shenin AV, Kokryakov VN: Aurelin, a novel antimicrobial peptide from jellyfish Aurelia aurita with structural features of defensins and channel-blocking toxins. Biochem Biophys Res Commun 2006, 348(2):514-523.

36. Marino A, Morabito R, Pizzata T, La Spada G: Effect of various factors on Pelagia noctiluca (Cnidaria, Scyphozoa) crude venom-induced haemolysis. Comp Biochem Physiol A Mol Integr Physiol 2008, 151(1):144-149.

37. Ehresmann DW, Deig EF, Hatch MT, Di Salvo LH, Vedros NA: Antiviral substances from California marine algae. J Phycol 1977, 13(1):37-40.

38. Ehresmann DW, Deig EF, Hatch MT: Antiviral properties of algal polysaccharides and related compounds. In 'Marine Algae in Pharmaceutical Science'. Volume Ath edition. Edited by Hoppe HA, Levring T, Tanaka Y. NY: Walter de Gruyter; 1979:293-302.

39. Richards JT, Kern ER, Glasgow L, Overall J, Deig E, Hatch M: Antiviral activity of extracts from marine algae. Antimicrob Agents Chemother 1978, 14:24-30.

40. Calvin NI, Ellis RJ: Water Soluble Extracts of Certain Marine Red Algae and Processes for Use Thereof; 1979. U.S. Patents 4,162,308 and 4,162,309. Referenced in Hydrobiologia 204/205, 1990, 99-104. SC Lindstrom and PW Garielson (eds) $13^{\text {th }}$ International Seaweed Symposium, 1990 Kluwer Academic Publishers.

41. Nonomura AL: Composition of matter from Cryptosiphonia woodii useful for the treatment of Herpes Simples virus; 1985. United States Patent no 4,522,814. Referenced in [42].

42. Neushul M: Method for the treatment of AIDS virus and other retroviruses. Developments in Hydrobiology 1990(58):99-104. 1988. U.S. Patent no. 4,783,446. Referenced in Neushal M, Antiviral carbohydrates from marine red algae.

43. Cheng SY, Huang K, Wang S, Wen ZH, Chen PW, Duh CY: Antiviral and Anti-inflammatory Metabolites from the Soft Coral. Sinularia capillosa. J Nat Prod 2010, 73(4):771-775.

doi:10.1186/1472-6882-14-77

Cite this article as: Ellithey et al: Cytotoxic and HIV-1 enzyme inhibitory activities of Red Sea marine organisms. BMC Complementary and Alternative Medicine 2014 14:77.

\section{Submit your next manuscript to BioMed Central and take full advantage of:}

- Convenient online submission

- Thorough peer review

- No space constraints or color figure charges

- Immediate publication on acceptance

- Inclusion in PubMed, CAS, Scopus and Google Scholar

- Research which is freely available for redistribution

Submit your manuscript at www.biomedcentral.com/submit 